\title{
Meningkatkan Kesehatan Ibu dan Anak di Posyandu Kenanga I Kelurahan Mamajang Dalam Kecamatan Mamajang Kota Makassar
}

\author{
Ruslan Hasani $^{1 *}$, Rosita Genggeng ${ }^{2}$ \\ 1*. Poltekkes Kemenkes Makassar, Jl. Monumen Emmy Saelan III Tidung, Kota Makassar, Indonesia 90222 \\ 2. Poltekkes Kemenkes Makassar, Jl. Monumen Emmy Saelan III Tidung, Kota Makassar, Indonesia 90222 \\ *e-mail : hasani.ruslan@gmail.com
}

\begin{abstract}
Abstrak
Tujuan pengabdian masyarakat ini adalah terbentuknya Kelas Ibu Hamil dan meningkatnya pengetahuan ibu-ibu hamil di Wilayah Kelurahan Mamajang Dalam mengenali tanda-tanda bahaya kehamilan. Kegiatan yang dilakukan adalah pemberian edukasi kesehatan dan Pembentukan Kelas Ibu hamil. Kegiatan ini dilaksanakan pada tanggal 25 dan 30 Agustus 2018 bertempat di Posyandu Kenanga I Kelurahan Mamajang Dalam Kecamatan Mamajang Kota Makassar. Metode dan alat yang digunakan 1). Pemberian edukasi Tanda Bahaya Kehamilan menggunakan media penyuluhan seperti gambar, pengeras suara. Media yang digunakan adalah Modul pembelajaran. Pihak-pihak yang terlibat dalam kegiatan ini adalah Petugas KIA Puskesmas Mamajang, Kader posyandu dan masyarakat khususnya ibu hamil. Hasil kegiatan adalah 1). Latar belakang pendidikan peserta adalah 10 orang yang terdiri dari 8 orang $(80 \%)$ berpendidikan Sekolah Menengah Atas (SMA) dan 2 orang (20\%) berpendidikan Sekolah Menengah Pertama (SMP). 2). Hasil Evaluasi Pre dan Post Test menunjukan bahwa terjadi peningkatan nilai hasil tes berkisar antara 40-55. 3). Hasil Evaluasi Tingkat Kemanfaatan selurh peserta (100\%) menilai sangat bermanfaat. Kesimpulan kegatan ini adalah 1). terbentuknya Kelompok ibu hamil di Posyandu Kenanga I Kelurahan Mamajang Dalam Kecamatan Mamajang Kota Makassar. 2). Terjadi peningkatan pengetahuan pada kelompok ibu hamil di Wilayah Kelurahan Mamajang Dalam Kecamatan Mamajang Kota Makassar tentang pengenalan tanda bahaya kehamilan.
\end{abstract}

Kata Kunci : Kelas Ibu Hamil, Tanda Bahaya Kehamilan

\section{Pendahuluan}

Kehamilan bagi seorang wanita adalah merupakan pengalaman yang sangat mengesankan dan merupakan peristiwa kehidupan yang besar maknanya bagi seorang wanita sehingga wanita dan pasangannya mengalami peningkatan kewaspadaan akibat terjadinya perubahan besar dalam diri wanita yang hamil tersebut. Kehamilan dan persalinan merupakan suatu kondisi yang perlu mendapat perhatian dari petugas kesehatan utamanya untuk mencegah terjadinya resiko komplikasi yang tidak diinginkan. Komplikasi terkait kehamilan dan persalinan dapat memberikan kontribusi secara langsung terhadapnya Angka Kematian Ibu (AKI) dan Angka Kematian Bayi (AKB). AKI adalah banyaknya wanita yang meninggal akibat kematian terkait dengan gangguan kehamilan atau penanganannya selama kehamilan, melahirkan dan dalam masa nifas (42 hari setelah melahirkan) per 100.000 kelahiran hidup (Kemenkes RI, 2014). AKI dapat menggambarkan tingkat kesadaran perilaku hidup sehat, status gizi dan kesehatan ibu, kondisi kesehatan lingkungan, tingkat pelayanan kesehatan terutama untuk ibu hamil, pelayanan kesehatan waktu ibu melahirkan dan masa nifas.

Upaya untuk menurunkan AKI dapat dilakukan dengan upaya preventif dan promotif dengan melibatkan semua unsur dalam masyarakat dan dilakukan secara terus menerus dan konsisten. Strategi yang dapat dilakukan adalah dengan menyelenggarakan kelas prenatal (kelas ibu hamil) (Machmudah, dkk, 2014)

Pemerintah Republik Indonesia dalam hal ini Kementerian Kesehatan mengharapkan tercapainya target Millenium Development Goal's (MDGs) pada tahun 2015 yaitu penurunan AKI menjadi 110/100.000 kelahiran hidup. Menurut data Kementerian Kesehatan RI AKI di Indonesia masih cukup tinggi dibandingkan dengan Negara-negara di ASEAN. Berdasarkan data demografi Indonesia tahun 2009, AKI masih sebesar 228 per 100.000 kelahiran hidup. Sementara di Kota Makassar AKI pada tahun 2015 sebanyak 5 kematian ibu dari 25.181 kelahiran hidup atau sekitar 19,86 per 100.000 KH (Dinkes Kota Makassar, 2016).

Salah satu upaya untuk menurunkannya yaitu dengan Program Perencanaan Persalinan Dan Pencegahan Komplikasi (P4K) Ibu Hamil yang merupakan upaya terobosan membangun potensi masyarakat, khususnya kepedulian masyarakat untuk persiapan dan tindak penyelamatan ibu dan bayi baru lahir (Dwijayanti, Putri, 2013).

Berbagai upaya telah dilakukan pemerintah untuk mengantisipasi masalah kematian ibu salah satu diantaranya melalui peningkatan peran kader Posyandu agar proaktif mendampingi ibu-ibu hamil dalam mendapatkan pelayanan 
kesehatan (K1-K4) serta penyuluhan - penyuluhan terkait menjaga kehamilan tetap sehat sehingga diharapkan ibu hamil sadar dan tahu akan kondisi kesehatannya dan diharapkan dapat mengambil langkah pertolongan pertama dirumah jika mengalami tanda bahaya kehamilan.

Kelompok Ibu Hamil adalah suatu kelompok yang dibentuk dengan tujuan meningkatkan pemahaman perempuan tentang kehamilan, persalinan dan nifas serta perawatan bayi baru lahir (Leeds, Grenvile \& Lanark, 2009; Schott \& Priest, 2008; MacDougall, Jane, 2005). Menurut club nutricia (2009); Nemours, 2009; NICE, 2008 terdapat 4 jenis kelompok ibu hamil yaitu : kelas khusus ibu hamil, kelas ibu hamil dan pasangan, kelas ibu hamil untuk kehamilan kedua dan seterusnya dan kelas ibu hamil privat.

Kelas khusus ibu hamil peserta hanya perempuan hamil, dimana dalam kelas dibahas masalah seputar kehamilan, persalinan dan perawatan bayi baru lahir dan juga membahas mengenai masalah pria. Kelas ibu hamil dan pasangan yaitu kelas dimana ibu dan pasangannya sama-sama mempersiapkan persalinan dimana ayah juga belajar proses kehamilan dan persalinan. Kelas ibu hamil untuk kehamilan kedua dan seterusnya merupakan kelas penyegaran untuk ibu dan pasangannya yang sudah pernah hamil dan melahirkan bayinya, dimana pengetahuan ibu dan pasangan tentang proses kehamilan dan persalinan diperbaharui. Kelas privat merupakan suatu kelas tertentu dalam menyongsong persalinan yang dilakukan oleh ibu bekerja, yang tidak memungkinkan untuk mengikuti kelas ibu hamil secara umum.

Cakupan pelayanan ibu hamil tahun 2015 di Kota Makassar menunjukkan Ada kesenjangan cakupan K1 (Kunjungan pertama ibu hamil) dan cakupan K4 (Kunjungan empat kali ibu hamil) dimana kunjungan K1 lebih tinggi dari K4 (Dinkes Kota Makassar, 2016).

Beberapa faktor yang dianggap mempengaruhi angka kunjungan cakupan K1 dan K4 diantaranya adalah masalah kurangnya pengetahuan ibu hamil tentang manfaat ANC (Ante Natal Care) dalam rangka pencegahan komplikasi kehamilan.

Ketidakpatuhan ibu hamil untuk melakukan kunjungan ANC ke unit pelayanan kesehatan selain karena alasan sibuk bekerja juga akibat kurangnya pengetahuan ibu hamil akan pentingnya melakukan ANC.

Melihat kondisi ibu hamil di wilayah Kelurahan Mamajang Dalam maka dianggap perlu mengembangkan suatu program yang bertujuan untuk meningkatkan pengetahuan ibu hamil dan meningkatkan kepatuhan ibu hamil dalam melakukan pemeriksaan ANC di unit pelayanan kesehatan yaitu dengan pendekatan peer group melalui pembentukan Kelompok Ibu Hamil.

\section{Metode Pelaksanaan}

Metode yang digunakan dan materi yang disajikan dalam kegiatan ini adalah penyuluhan berupa ceramah dan tanya jawab mengenai Tanda Bahaya Kehamilan.

A. Pengenalan dan persiapan

Adapun jadwal kegiatan disusun sebagai berikut :

1. Persiapan

Persiapan yang dilakukan meliputi kegiatan-kegiatan sebagai berikut :

a) Mengajukan surat ijin kegiatan

b) Merancang metode kegiatan

c) Persiapan materi dan media penyuluhan

\section{Pelaksanaan}

Kegiatan pengabdian kepada masyarakat ini dilaksanakan selama dua hari yaitu pada tanggal 25 Agustus 2018 dengan melakukan penyuluhan kesehatan dan 30 Agustus 2018 pembentukan kelas ibu hamil bertempat di Posyandu Kenanga I Kelurahan Mamajang Dalam Kecamatan Mamajang Kota Makassar.

\section{Hasil}

A. Karakteristik Peserta

Peserta penyuluhan adalah kelompok sasaran ibu hamil di Posyandu Kenanga I Kelurahan Mamajang Dalam Kecamatan Mamajang Kota Makassar.

Tabel 1. Daftar peserta kelompok ibu hamil di Posyandu Kenanga I Kelurahan Mamajang Dalam Kecamatan Mamajang Kota Makassar.

\begin{tabular}{|c|c|c|c|c|}
\hline No. & Responden & Umur (Tahun) & Pendidikan & Alamat \\
\hline 1 & Ny. Z & 23 & SMP & RT 01 RW 04 \\
\hline 2 & Ny. M & 30 & SMA & RT 01 RW 04 \\
\hline 3 & Ny. I & 27 & SMA & RT 02 RW 04 \\
\hline 4 & Ny. In & 29 & SMA & RT 02 RW 04 \\
\hline 5 & Ny. F & 24 & SMA & RT 02 RW 04 \\
\hline 6 & Ny. A & 22 & SMA & RT 01 RW 04 \\
\hline 7 & Ny. F & 19 & SMA & RT 01 RW 04 \\
\hline 8 & Ny. R & 20 & SMA & RT 01 RW 04 \\
\hline 9 & Ny. Ra & 24 & SMA & RT 02 RW 04 \\
\hline 10 & Ny. K & 19 & SMP & RT 02 RW 04 \\
\hline
\end{tabular}


Berdasarkan Tabel 1. Dapat dilihat bahwa jumlah peserta sebanyak 10 orang dengan latar belakang pendidikan SMP sebanyak 2 orang dan SMA sebanyak 8 orang dengan rentang usia termuda berumur 19 tahun dan tertua berumur 30 tahun.

B. Respon Peserta

Untuk mengetahui manfaat kegiatan pembentukan kelompok ibu hamil di Kelurahan Mamajang Dalam Kecamatan Mamajang Kota Makassar, maka dilakukan analisis kemanfaatan dengan penyebaran kuesioner kepada peserta setelah selesainya kegiatan.

Instrumen penilaian Analisis tingkatan kemanfaatan yang digunakan menggunakan skala likert yang terdiri dari 5 point jawaban yang setiap jawaban mempunyai point nilai tersendiri mulai yang terendah 1 sampai yang tertinggi 4, yaitu Sangat Bermanfaat (SB) dengan nilai 4, Bermanfaat (B) dengan nilai 3, Ragu-Ragu (RR) dengan nilai 2, Tidak Bermanfaat (TB) dengan nilai 1 dan Sangat Tidak Bermanfaat (STB) dengan nilai 0.

Berdasarkan hasil evaluasi Tingkat Kemanfaatan pembentukan kelompok ibu hamil di Kelurahan Mamajang Dalam Kecamatan Mamajang Kota Makassar didapatkan hasil seluruh peserta pelatihan (100\%) menilai bahwa kegiatan kelompok ibu hamil sangat bermanfaat dengan nilai total yang diperoleh sebesar 40. Sehingga dapat ditarik kesimpulan bahwa semua peserta / anggota kelompok ibu hamil merasakan kegiatan ini adalah Sangat Bermanfaat.

C. Dampak

Dampak positif dari terselenggaranya program pengabdian masyarakat ini, yakni bertambahnya pengetahuan kelompok sasaran ibu hamil dalam dalam hal pengenalan tanda bahaya kehamilan awal dan lanjut yaitu pemahaman tentang perdarahan pervaginam, penyakit hipertensi pada ibu hamil, hyperemesis gravidarum, anemia dalam kehamilan, sakit kepala hebat, penglihatan kabur, bengkak pada wajah, kaki dan tangan, keluar cairan pervaginam, gerakan janin berkurang nyeri perut yang hebat, kelainan letak dan polihidramnion.

Berdasarkan hasil evaluasi Pre dan Post Test peserta penyuluhan kelompok ibu hamil didapatkan hasil yaitu sebagian besar peserta kelompok ibu hamil yaitu 9 orang $(90 \%)$ mendapatkan nilai antara 41 - 60 dengan predikat sangat memuaskan dan satu orang ibu hamil (10\%) mendapat nilai antara nilai 21 - 40 dengan predikat memuaskan. Sehingga dapat ditarik kesimpulan bahwa sebagian besar anggota kelompok ibu hamil dapat memahami dengan sangat baik seluruh materi yang telah diberikan pada hari pertama dimana terlihat rata-rata selisih nilai yang diperoleh adalah antara $41-60$.

\section{Kesimpulan}

Berdasarkan hasil kegiatan dan pembahasan pada kegiatan pengabdian masyarakat ini, maka dapat disimpulkan sebaga berikut:

A. Terjadi peningkatan pengetahuan pada kelompok ibu hamil di Wilayah Kelurahan Mamajang Dalam Kecamatan Mamajang Kota Makassar tentang pengenalan tanda bahaya kehamilan.

B. Kelompok ibu hamil di Wilayah Kelurahan Mamajang Dalam Kecamatan Mamajang Kota Makassar menilai kegiatan kelompok ibu hamil yang diikutinya dirasakan sangat bermanfaat sekali.

\section{Rekomendasi}

A. Laporan ini sebagai sumber referensi bagi pengabdi yang berminat melakukan pengabdian kepada masyarakat dengan topik yang sama

B. Kepada pihak terkait laporan ini sebagai masukan dalam pengambilan kebijakan dibidang kesehatan

\section{Daftar Pustaka}

AR, Chaerunnisa, dkk, 2014. Hubungan Perilaku Ibu hamil Terhadap Pemanfaatan ANC di Puskesmas Mamajang Kota Makassar, Bagian AKK FKM Unhas Makassar.

Club Nutricia. Kelas prenatal. Diunduh dari.http://www.clubnutricia.co.id/Pages/home.aspx pada tanggal 5 April 2018.

Dwijayanti, Putri. 2013. Analis Implementasi Program Perencanaan Persalinan dan Pencegahan Komplikasi (P4K) oleh Bidan Desa di Kabupaten Demak. Jurnal Kesehatan Masyarakat 2013, Volume 2, Nomor 1

Dinkes Kota Makassar. 2016. Profil Kesehatan Kota Makassar 2015

Dinkes Prov. Sul-sel. 2015. Profil Kesehatan Prov Sul-sel 2014.

Kemenkes RI (2014). Indo Datin, Pusat Data dan Informasi, Jakarta

Leeds, Grenvile \& Lanark (2009). Pregnancy health unit: Pregnancy classes. Diunduh dari ttp://www.healthunit.org/pregnancy/pregnancy/pregnancy_prenatal_classes.htm pada tanggal 11 April 2018. 
MacDougall, Jane (2005). Pregnancy week by week : Understand the changes and chart the progress of you and your baby. London : Collins National Collaborating Centre for Women's and Children's Health (2008). Antenatal care : Routine care for the healthy pregnant woman. Di unduh dari http://guidance.nice.org.uk/CG62/Guidance/pdf/English pada tanggal 09 April 2018

Machmudah, dkk. 2014. Ipteks Bagi Masyarakat (Ibm): Pembentukan Kelompok Ibu Hamil Di Desa Kangkung Mranggen Demak, Fakultas Ilmu Keperawatan dan Kesehatan, Universitas Muhammadiyah Semarang.

Nemours (2009). Kidshealt : Birthing classess. Diunduh dari http://kidshealth.org/parent/pregnancy_newborn/pregnancy/birth_class.html\#a_What_T ypes_of_Classes_Are_Available_ pada tanggal 11 April 2018

Schott and Priest (2008). Kelas antenatal. Jakarta : EGC 